\title{
FPGAベースリアルタイムビジョン
}

\author{
平 井 慎 $\cdots * 1$ 座光寺 正 和*2 増 㴊 章 洋*3 坪 井 辰 彦*1
}

\section{FPGA-based Realtime Vision}

\author{
Shinichi Hirai*1, Masakazu Zakouji*2 ${ }^{*}$ Akihiro Masubuchi*3 ${ }^{* 3}$ and Tatsuhiko Tsuboi*1
}

\begin{abstract}
In this article, we will develop a realtime vision system based on FPGA's and will evaluate the performance of the developed FPGA-based vision system experimentally. First, we will describe the developed FPGA-based vision system. Secondly, we will implement three vision algorithms on the vision system: computation of the image gravity center, detection of object orientation using a radial projection, and the computation of Hough transform. We will then execute these algorithms on the FPGA-based realtime vision system.
\end{abstract}

Key Words: Vision, Realtime, FPGA, Logic Circuit, Parallel Processing

\section{1.はじめに}

本論文では, FPGA（Field Programmable Gate Array）を 基にリアルタイムビジョンシステムを構築し, FPGA ベースリ アルタイムビジョンシステムの性能を, 実験的に評価する.

現在のビジョンシステムは，大きく二つの手法に分類できる. 一つは,ソフトウェアによる手法で，もう一つは ASICによる 手法である.ソフトウェアによる手法では, ビジョンアルゴリズ ムはプログラムの形で記述され，汎用の CPU上で実行される. この手法では，様々なアルゴリズムを，低いコストで実装する ことができる，一方，アルゴリズムによっては，多くの計算時間 を要し、リアルタイムで実行することができない，ASICによ る手法では, ビジョンアルゴリズムは論理回路の形で記述され， アルゴリズムに特化して設計，製造された LSI 上で実行される， すでに,フーリエ変換 [1], 八フ変換 $[2]$, 正規化相関 [3] [4], ス テレオビジョンアルゴリズム [5] など, 多くのアルゴリズムが ASIC 上に実装されている．また，論理回路とアナログセンサ回 路から成るLSI も試作されている [6] [7]. ASICによる手法で は，高速な演算が可能である反面，ASIC 上の回路設計と製造 に, 多大の労力とコストを要する。一般に, 万単位以上のマー ケットが見込めないと, ASIC を設計，製造するメリットはな いといわれる. 結局, ソフトウェアによる手法は, 高いフレキシ ビリティを持つがリアルタイム性に少り，ASICによる手法は

\footnotetext{
原稿受付 2002 年 12 月 19 H

*1立命館大学:ロボティクス学科

*2七イコーエプソン (株)

*3ソニー (株)

${ }^{* 1}$ Department of Robotics, Ritsumeikan University

*2 Seiko Epson Corp.

${ }^{* 3}$ Sony Corp.
}

リアルタイム性に優れるがフレキシビリティとコストパフォー マンスに少る。

フレキシビリティとリアルタイム性とのこのようなジレンマ を解決するために，本論文では FPGA ベースビジョンシステ ムを構築する，FPGA とは，ユーザが論理回路を書き込み，動 作させることが可能な LSI である。ユーザは, ビジョンアル ゴリズムに特化して設計された論理回路を FPGA 上に実装し, FPGA 上で回路を動作させることにより, ビジョンアルゴリズ ムを実行することができる。ビジョンアルゴリズムは論理回路 の形で実行されるので, リアルタイム性は確保される。論理回 路を再度設計し, FPGA に実装することができるので, フレ キシビリティも確保される。すでに，いくつかのビジョンアル ゴリズムがFPGA に実装されている，例えば，二次元離散コ サイン変換 [8], Parzen Window 法による画像識別 [9], 医療診 断における集中度フィル夕 [10], 盢み込みによる画像復元 [11], CORDIC を用いたハフ変換 $[12]$ が実装されている。しかし, 実 装例では，フィルタリングなど局所演算に基づくビジョンアル ゴリズムが多く，二次元フーリエ変換やハフ変換に代表される 大域演算に基づくビジョンアルゴリズムの実装例は少ない。そ の原因として, 大域演算を含むビジョンアルゴリズムを実行す る論理回路を，ハードウェア記述言語を用いて設計することが 容易ではない点が挙げられる. 大域演算を含むビジョンアルゴ リズムの回路設計においては, 大域演算の結果や最終的な結果 を画像で評価しながら，デバッグを進める必要がある。ハード ウェア記述言語を用いた設計では，このようなデバッグに手間 と時間を要するため, 大域演算に基づくビジョンアルゴリズム の実装が困難となっている。

以上の考察から, 本論文では, FPGA ベースリアルタイムビ ジョンシステムを構築するとともに, C 言語ベースの回路設計 
を用いてビジョンアルゴリズムの回路設計を試みる。まず，構 築したFPGA ベースビジョンシステムのハードウェアを紹介 する。次に, FPGA ビジョンシステムに三つのアルゴリズム， 画像重心の計算, 放射状射影による姿勢の検出, ならびにハフ 変換の計算を実装する。最後に, FPGA ベースビジョンシステ ムで，これらのアルゴリズムを実行した結果を述べる。

\section{FPGA ベースビジョンシステム}

\section{1 ハードウェア構成}

本章では, FPGA を用いたビジョンシステムについて述べる. 物体操作や人間識別など多くのアプリケーションにおいて，ビ ジョンシステムは連続する一連の画像をリアルタイムで処理す ることが要求される。ささに, 様々な使用環境に適合できるフ レキシビリティを有することが求められる．多くのビジョンア ルゴリズムは並列性が高く, 並列処理を実現することにより計 算時間を短縮することが期待できる。一方, FPGA 上に論理回 路を並列に配置することにより，並列処理を容易に実現できる. したがって, FPGA ベースビジョンシステムに並列性の高いビ ジョンアルゴリズムを実装することにより, リアルタイム性と フレキシビリティの双方を達成することができる。

Fig. 1 にFPGA ベースビジョンシステムのプロトタイプを示 す.このプロトタイプは, FPGA ボード, ビデオデコーダボー ド，ビデオエンコーダボード, SRAM ボード, PC インタフェー スから構成される. FPGA ボードは, エスケーエレクトロニク ス社製 CM69であり，FPGA としてザイリンクス社製 Vertex 2000-E が搭載されている。この FPGA 上には, 200 万ゲート 相当の論理回路を構築できる. ビデオデコーダボード，エンコー ダボードは, 三菱電機マイコン機器ソフトウエア社製 MU200VDEC, MU200-VENCであり, ビデオエンコード, デコード チップとして Brooktree 社製 Bt812 と Bt856 が使われている. SRAM ボードMU200-SRAM は, 1[MB] のメモリを提供する. NTSC 信号で送られる CCD カメラからの連続画像は, ビデオ デコーダボードでデジタル信号に变換され，FPGA 上に実装 される画像処理回路に送られる。画像処理回路は, 必要ならば SRAM を記憶回路として使いながら画像処理を進める. 画像処 理回路は PC 上で設計される. 設計された回路は，PCインタ

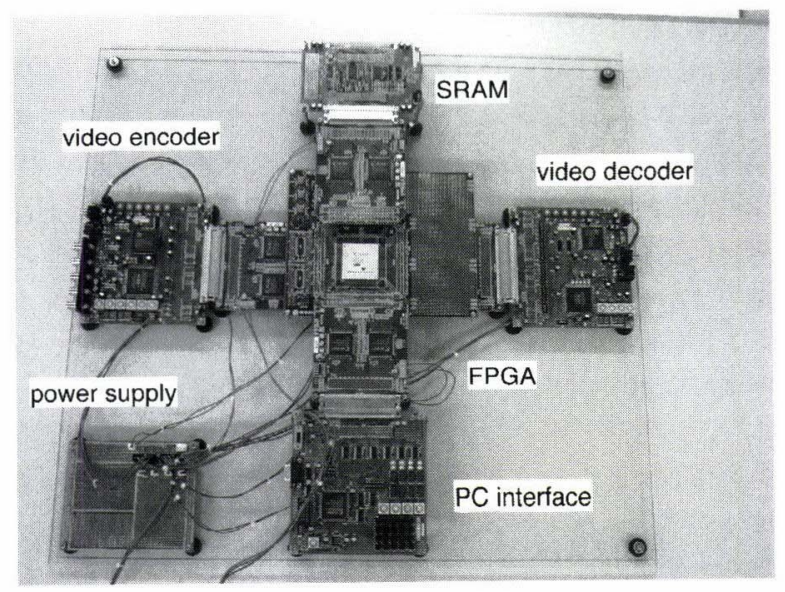

Fig. 1 Prototype of FPGA-based vision system
フェース MU200-EX40を通って，FPGA 上にダウンロードさ れる。

\section{$2.2 \mathrm{C}$ 言語ベース回路設計}

ビジョンアルゴリズムの回路設計においては, ハードウェア記 述言語（HDL）の代わりに，C/C++言語ベースの回路設計を 導入する. 従来より, 多くのビジョンアルゴリズムが, $\mathrm{C} / \mathrm{C}++$ 言語を用いて開発されている。したがって，C/C++言語を用い た回路設計を導入することにより，アルゴリズムの開発と論理 回路の設計を，シームレスに遂行することができる。また，ビ ジョンシステムの開発では, 設計と評価を繰り返すことが多く, 回路規模が大きいため論理合成に時間を要する。 C/C +十言語 による回路設計では，C/C++言語の段階で設計を評価するこ とができるため, 論理合成の回数を減らし, 開発時間を短縮す ることが期待できる。以上の理由から，C/C++言語を用いた 論理回路設計を導入する.

本論文では，C/C++で記述したソースを HDL へ変換するソ フトである SystemCompiler を使用する. SystemCompiler で は, 論理回路の記述に CycleC を用いる. CycleC は, C/C++ のサブセットである. CycleCで設計した論理回路は, PC 上で コンパイル，実行することができるので，論理合成することな く論理回路を検証することができる、さらに，テストプログラ ムやテストパターンを PC 上で容易に構成できるため, 効率的 な回路の検証が可能である. 以上の点より, SystemCompiler を導入することにより，設計した論理回路を短時間で検証する ことができる. CycleCによる記述は，ハードウェア記述言語 VerilogHDL あるいはVHDL に変換される。 ハードウェア記述 言語に変換された設計を論理合成し, FPGA 上に実装する。以 上のように, C/C++言語ベースの論理設計を導入することに より,ビジョンアルゴリズムを短期間で FPGA 上に実装するこ とができる. Table 1 に, CycleCによるセレクタの記述例を 示す、表に示すように, $\mathrm{C} / \mathrm{C}++$ 言語のクラスとメソッドを用 いて, 論理回路を記述する.

ビデオデコーダボード, エンコーダボード, SRAM ボードと のインタフェースは, あらかじめ HDL で記述されている。 ビ

Table 1 Description of selector in SystemCompiler

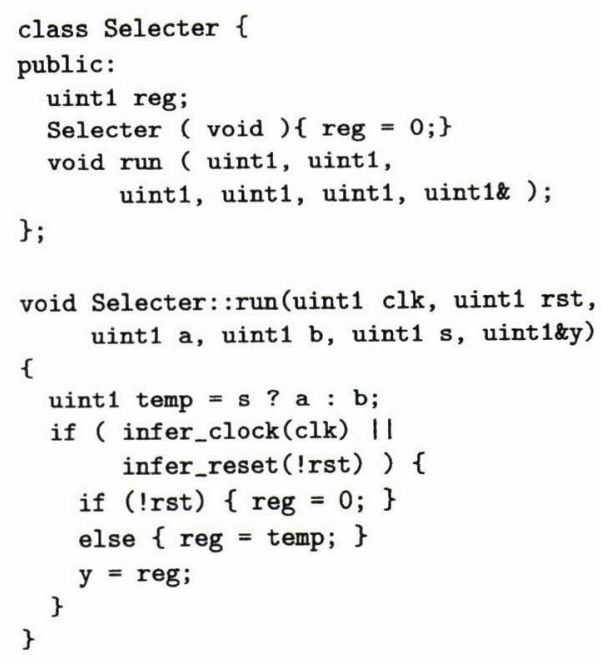


ジョンアルゴリズムを CycleC で記述し, SystemCompiler で HDL に変換した後に，インタフェースの HDL 記述と接続す る.この手法により設計者は，ビジョンアルゴリズムそのもの の論理回路記述に専念することができ，効率の良い開発が期待 できる.

\section{3. ビジョンアルゴリズムの FPGA 実装}

本章では，三つのビジョンアルゴリズムを，FPGA 上に実装 する，すなわち，画像重心の計算，放射状射影による姿勢の検 出.[13]，ならびにハフ変換の計算である.

\section{1 画像重心の計算}

まず，画像重心の計算を FPGA 上に実装する，計算アルゴリ ズムを簡単に説明する.グレースケール画像の幅を $W$ ，高さを $H$, 格子点 $(x, y)$ におけるピクセル值を $g(x, y)$ とする。画像 重心の座標は,

$$
\left[\begin{array}{l}
c_{x} \\
c_{y}
\end{array}\right]=\left[\begin{array}{l}
W_{x} / W \\
W_{y} / W
\end{array}\right]
$$

ただし

$$
\begin{aligned}
{\left[\begin{array}{l}
W_{x} \\
W_{y}
\end{array}\right] } & =\sum_{x=0}^{W-1} \sum_{y=0}^{H-1}\left[\begin{array}{l}
x \\
y
\end{array}\right] g(x, y), \\
W & =\sum_{x=0}^{W-1} \sum_{y=0}^{H-1} g(x, y)
\end{aligned}
$$

で与えられる。上式に示すように，画像重心の計算は，三つの 総和と二つの除算から成る。総和 $W_{x}, W_{y}, W$ の計算は，画像 のキャプチャに並行して央行することができる，すると，画像 のキャプチャが終った時点で，除算を実行することができるささ らに，二つの除算を並列に実行することができる。結果として， 画像重心の計算は, 画像キャプチャの終了後, 除算 1 回分の計 算時間で終了する.Fig. 2 に，画像重心を計算する論理回路を 示す. 論理回路の入力信号は, START, X, Y, Gであり, 出力信 号は, COG_X, COG_Y, COMPLETE である. 入力信号 START は, 計算開始を指示する。信号 X と Y は画像の座標值を表し，信号 $\mathrm{G}$ は画素値 $g(x, y)$ を表す。出力信号 COG_X とCOG_Y は, 画像 重心の座標値を表す，信号 COMPLETE は, 計算完了を知らせる. モジュール SUM は, 画像のキャプチャと並行して, 式 (2) で 与えられる $W_{x}, W_{y}, W$ を計算する。総和の計算が終了した 後，信号 div_start が除算開始を指示する.

\section{2 放射状射影}

次に，放射状射影の計算を，FPGA上に実装する。放射状 射影に関して簡単に説明する。グレースケール画像上に座標系

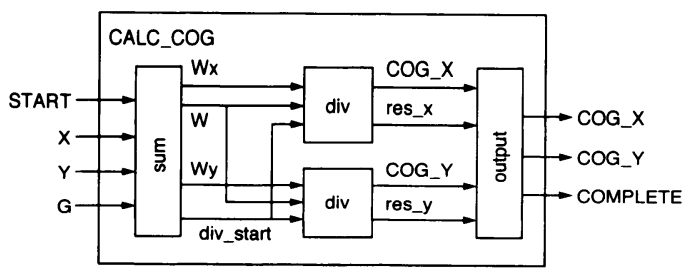

Fig. 2 Circuit to compute gravity center
$O-x y$ を固定する. 画像上の点 $(x, y)$ における画素值を $g(x, y)$ とする. 画像重心から放射状に伸びる半直線に沿って, 画素値を 積分する. 半直線が $x$ 軸と成す角度を $\theta$ で表す。このとき，画 素值の積分は, パラメータ $\theta$ の関数であり, 次式で与えられる.

$$
R(\theta)=\int_{0}^{\infty} g\left(c_{x}+\xi \cos \theta, c_{y}+\xi \sin \theta\right) d \xi .
$$

ここで， $c_{x}$ と $c_{y}$ は，画像重心の座標值を表す。間 $[0,2 \pi]$ で 定められる積分值 $R(\theta)$ 全体を, 放射状射影と呼ぶ.

参照画像を $g_{\text {template, }}$, 入力画像を $g_{\text {input }}$ で表す. 入力画像中 の物体の姿勢を角度 $\alpha$ で表す．参照画像と入力画像における放射 状射影を， $R_{\text {template }}$ と $R_{\text {input }}$ で表す. 二つの射影 $R_{\text {template }}$ と $R_{\text {input }}$ は, 次に示す関係を満たす。

$$
R_{\text {template }}(\theta)=R_{\text {input }}(\theta+\alpha), \quad \forall \theta .
$$

二つの射影間に，次式で与えられる䛊差関数を導入する.

$$
S(\tau)=\int_{0}^{2 \pi}\left|R_{\text {template }}(\theta)-R_{\text {input }}(\theta+\tau)\right| d \theta .
$$

この䛊差関数は, $\tau=\alpha$ で最小值 0 を取る.したがって, 上式 で与えられる䛊差関数を最小化することにより, 姿勢角 $\alpha$ を算 出することができる.

式（3）で与えられる計算は，画像のキャプチャが終了するま で開始できない.すなわち，この計算は，画像のキャプチャと 並行に計算することができず，リアルタイム処理の妨げになる. そこで，八フ変換における投票の考えを導入し，画像のキャプ チャと並行に射影を計算できるように，アルゴリズムを構成す る. 式 (3)より,

$$
\begin{aligned}
& x=c_{x}+\xi \cos \theta, \\
& y=c_{y}+\xi \sin \theta .
\end{aligned}
$$

パラメータ $\xi$ を消去すると，

$$
\tan \theta=\frac{y-c_{x}}{x-c_{y}}
$$

上式は, 点 $(x, y)$ における画素值が, 角度 $\theta$ で定められる積分 に奇与することを意味する。すなわち，(6) 式で計算された角 度 $\theta$ に対応する積分 $R(\theta)$ に, 画素値 $g(x, y)$ を加算すればよ い. 画像のキャプチャにおいて, 画素值は論理回路に順次与え られる。したがって, 画像のキャプチャと並行して, すべての 画素值を対応する積分值に加算することができる，以上の投票 を, Table 2 に示す.

Fig. 3 に，投票により放射状射影を計算する回路を示す。こ の回路は, 6 本の入力信号 START, COG_X, COG_Y, X, Y, G と 1 本の出力信号 COMPLETE を持つ. モジュール subtracter は, $\Delta x=x-c_{x}$ と $\Delta y=y-c_{y}$ を計算する. モジュール atanは, $\theta=\arctan (\Delta y / \Delta x)$ を計算する. 射影 $R(\theta)$ の值は, バッファ に保存される. 信号 THETA を指定し, 角度 $\theta$ における積分值 をバッファから読み出す．読み出された積分值 R_THETAに，信 号 $\mathrm{G}$ で表される画素值 $g(x, y)$ が加算され, 再び積分值をバッ ファに書き込む。 
Table 2 Voting in computation of projection initialize array $R(\theta)$

for $(x, y)=(0,0),(0,1), \cdots,(W-1, H-1)$ do

$\Delta x=x-c_{x}, \Delta y=y-c_{y}$

compute $\theta=\arctan (\Delta y / \Delta x)$

increase $R(\theta)$ by pixel value $g(x, y)$

end

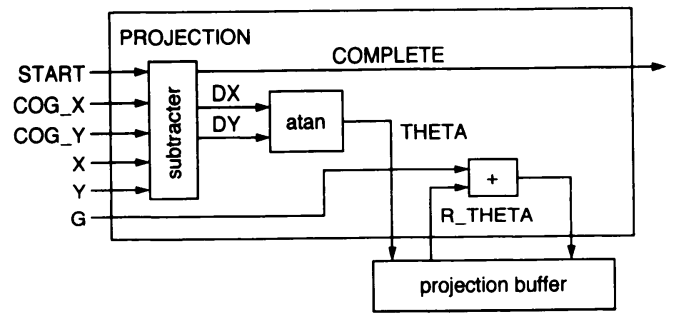

Fig. 3 Circuit to compute projection

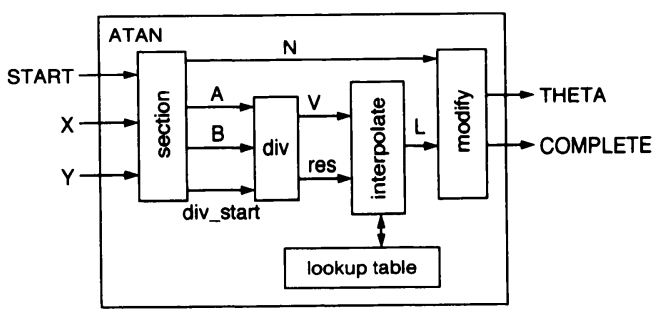

Fig. 4 Circuit to compute function atan

モジュール atanを，Fig.4に示す．あらかじめ，区間 $[0,1]$ 内にいくつかの代表值 $v$ を選び， $\theta=\arctan (v)$ を計算する. 代表值に扔ける $v$ と $\theta$ の組を，ルックアップテーブルに保存し ておく. 点 $(x, y)$ が $0 \leq y \leq x$ を満たすとき, $\arctan (y / x)$ を 計算する回路を構成しよう，まず， $y / x$ を計算する．商は，区間 $[0,1]$ に含まれる.したがって, 関数值 $\arctan (y / x)$ は, ルック アップテーブル内の代表値を補間することで計算することができ る。モジュール interpolateは，この補間を実行する回路であ る. 任意の点 $(x, y)$ における関数伹は，この補間を用いて計算す ることができる。例えば，点 $(x, y)$ が $0 \leq-x \leq y$ を満たす場 合, 関数值 $\arctan (y / x)$ の值は, $\pi-\arctan (-x / y)$ に等しい. 商 $(-x / y)$ の值は区間 $[0,1]$ に含まれるので, $\arctan (-x / y)$ の值はモジュール interpolateにより計算することができる. そこで, $x$ と $y$ の符号, 絶対值 $|x|$ と $|y|$ の大小関係により, $x-y$ 平面を 8 個の領域に分割すると, どの領域に対しても，モ ジュール interpolate を用いて, 関数值 $\arctan (y / x)$ の值を 求めることができる.モジュール sectionは，点 $(x, y)$ に対応 する領域を求める。信号 $\mathrm{N}$ に領域番号, 信号 $\mathrm{A}$ に $|x|$ と $|y|$ の 小さい方，信号 Bにもう一方を出力する．モジュール modify は, $\arctan (A / B)$ と $N$ の值から, 関数值 $\arctan (y / x)$ を構成 する。

Fig. 5 に，式（5）で与えられる誤差関数を最小化する論理回 路を示す。モジュール angle_genは, 二つの信号 theta_temp, theta_input を生成する。それぞれ，式（5）中の角度 $\theta$ と $\theta+\tau$ に対応する．対応する放射状射影の值 $R_{\text {template }}(\theta)$

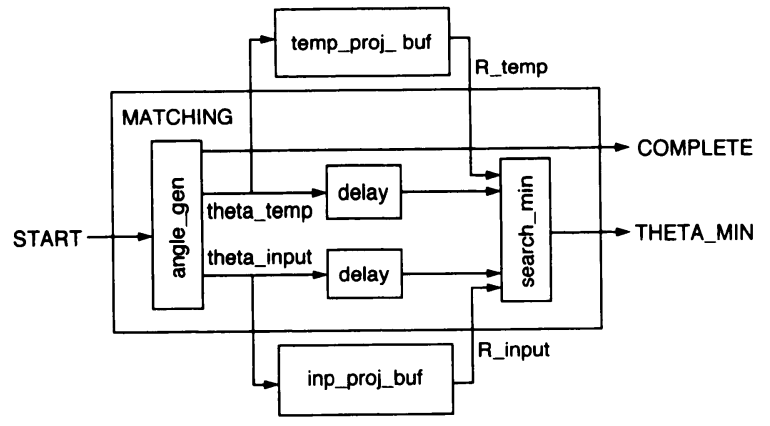

Fig. 5 Circuit to compare projections

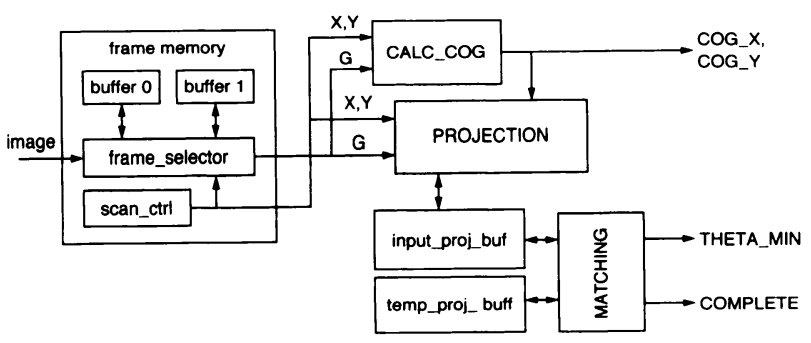

Fig. 6 Circuit to detect planar motion

と $R_{\text {input }}(\theta+\alpha)$ は, バッファtemp_proj_buf とバッファ inp_proj_buf から読み込まれる。モジュール search_minは, 射影值の絶対差分の総和を計算し, 計算伹が最小となる角度 $\alpha$ を求める.

物体と背景が明確に分離でき, 画像内に複数の物体が存在し ない場合, 画像重心を計算することにより, 平面運動物体の位 置を求めることができる.さらに, 参照画像と入力画像の放射 状射影を比較することにより, 平面運動物体の姿勢を算出する ことができる. Fig. 6 に, 重心計算と放射状射影の比較により, 平面運動物体の位置と姿勢を計算する回路を示す。ビデオデコー ダボードでは，ダブルバッファリングにより，画像を連続的に キャプチャする。モジュール frame_selector は, 二つの画像 バッファを切り替える. モジュール scan_ctrl は, 画面全体を 巡回する座標值 $(x, y)$ を生成する。参照画像の射影は, あらか じめ計算され，バッファtemp_proj_buf に格納されている．信 号 COG_X と COG_Y が平面運動物体の位置を, 信号 THETA_MIN が 姿勢を表す。

\section{3 八フ変換}

ハフ変換は，ビジョンの基本的なアルゴリズムの一つであり， 応用範囲が広い，例えば，八フ变換を用いることにより，平面 運動物体の位置と姿勢を，照明変動やオクルージョンに対して ロバストに検出できることが知られている[14]. 八フ変換は時 間を要する処理であるが, 並列性が高いため, FPGA ベースビ ジョンに実装することにより，高速な実行が期待できる，本節 では，八フ変換をFPGA ベースビジョンに実装する。

ハフ変換は, 離散画像 $g(x, y)$ からハフ平面 $H(\rho, \theta)$ への変 換である。まず, 格子点 $(x, y)$ に対して, 次式を満たす $\rho$ と $\theta$ の組を求める.

$$
(-\sin \theta) x+(\cos \theta) y=\rho .
$$


次に, 上式を満たす $\rho$ と $\theta$ の組に対して, $H(\rho, \theta)$ の值を画素 值 $g(x, y)$ だけ増加させる.すべての画素值に対して以上の計 算を行った結果が, 八フ変換である. 上式は, 点 $(x, y)$ を通る 直線群を表し, $\rho$ は直線の原点からの符号付き距離を, $\theta$ は直線 と $x$ 軸が成す角を表す. 以上の計算過程を, Table 3 に示す.

Fig. 7 に，八フ変換を計算する回路の概略を示す. 制御信 号は省略する。区間 $[0,2 \pi]$ を $K$ 分割し, $\Delta \theta=2 \pi / K$ とす る。このとき, 角度 $\theta$ の值は, $k \Delta \theta(k=0,1, \cdots, K-1)$ で ある.角度 $k \Delta \theta$ に対する計算を, Fig. 8 に示すモジュール $\operatorname{voting}(k)$ で行う. 角度 $k \Delta \theta$ における八フ変換の結果は, バッ ファhough_buf $(k)$ に格納される. モジュール voting $(k)$ の入 力信号は画像の座標值 $\mathrm{X}, \mathrm{Y}$, ならびに画素值 Gである. モジュー ルには， $c_{k}=\cos (k \Delta \theta)$ と $s_{k}=\sin (k \Delta \theta)$ の值が，あらかじ め記憶されている. モジュール calc_rhoで $\rho_{k}=c_{k} y-s_{k} x$ の值を計算し, 信号 RHO_k に出力する. 距離 $\rho_{k}$ の計算が完了 後，バッファhough_buf $(k)$ を更新する。まず，信号 RHO_k を 指定し, 距離 $\rho_{k}$ に対する積分值をバッファから読み出す. 読 み出された積分值に, 信号 $\mathrm{G}$ で表される画素値 $g(x, y)$ を加 算し，再び積分值をバッファに書き込む．以上の計算は，角度 $k \Delta \theta(k=0,1, \cdots, K-1)$ に対して, 並列に実行することがで きる、したがってハフ変換の計算は, モジュール $\operatorname{voting}(k)$ と バッファhough_buf $(k)$ を，角度の分割数 $K$ 個並列に並べた， Fig. 7 に示す回路で実現される.

Table 3 Voting in computation of Hough transform initialize array $H(\rho, \theta)$

$$
\begin{aligned}
& \text { for }(x, y)=(0,0),(0,1), \cdots,(W-1, H-1) \text { do } \\
& \text { for } k=0,1, \cdots, K-1 \text { do } \\
& \quad \text { compute } \theta=k \Delta \theta \\
& \quad \text { compute } \rho=(-\sin \theta) x+(\cos \theta) y \\
& \text { increase } H(\rho, \theta) \text { by pixel value } g(x, y)
\end{aligned}
$$

end

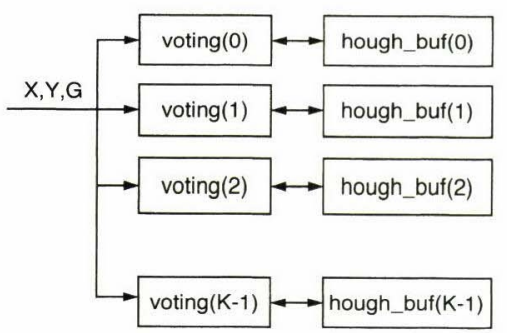

Fig. 7 Circuit to compute Hough transform

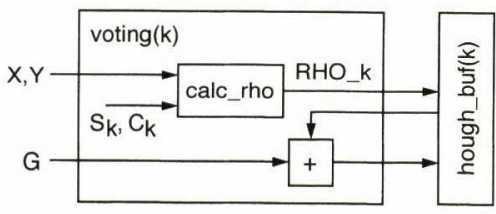

Fig. 8 Circuit to perform voting

\section{4. 実 験 的 評価}

\section{1 画像重心の計算}

画像重心を計算する回路を, FPGA ベースビジョンシステム に実装した．画面中央部 $256 \times 256$ [pixel] の領域に対して画像 重心を計算する。このとき FPGAは， $2 \%$ のゲートを消費した。 また，回路を $58[\mathrm{MHz}]$ で駆動できることが, シミュレーショ ンで判明した。実験では, 画像のキャプチャに合せて, 回路を $12[\mathrm{MHz}]$ で駆動した。除算 1 回は32 クロックで終了するので, 画像重心の計算はキャプチャ後約 2.7 [ $\mu \mathrm{sec}]$ で完了する. Fig. 9 に, 画像重心の計算例を示す。水平線と垂直線が, 計算された 画像重心の座標を表す。四に示すように，画像重心をリアル夕 イムで計算することができる。

\section{2 放射状射影}

重心計算と放射状射影の比較により, 物体の平面運動を検出す る論理回路を, FPGA ベースビジョンに実装した。画面中央部 $256 \times 256$ [pixel] の領域に対して画像重心と放射状射影を計算し, 放射状射影のマッチングを行う。角度は，64段階で表される。こ のときFPGA は，13\%のゲートを消費したＦig. 10 に，実装 回路で消費されたFPGA のゲートを示す．回路を $24[\mathrm{MHz}]$ で 駆動できることが，シミュレーションで判明した。実験では，画 像のキャプチャに合わせて, 回路を $12[\mathrm{MHz}] て ゙$ 駆動した。一画

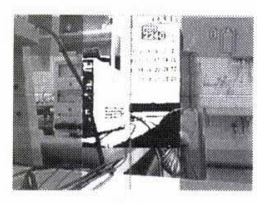

(a)

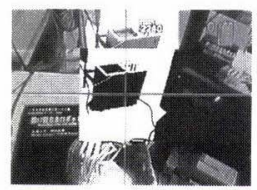

(d)

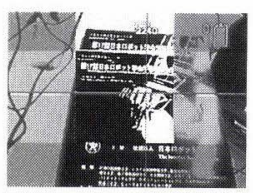

(g)

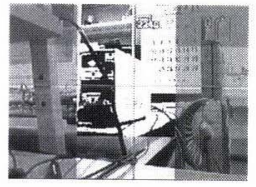

(b)

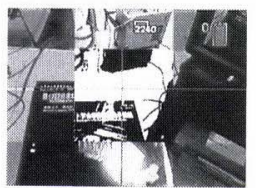

(e)

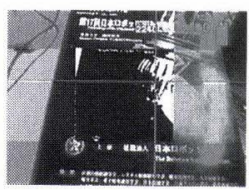

(h)

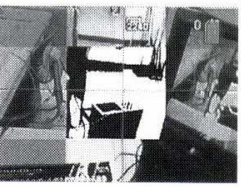

(c)

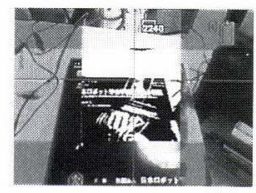

(f)

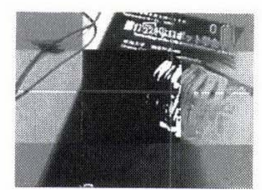

(i)
Fig. 9 Detection of image gravity center

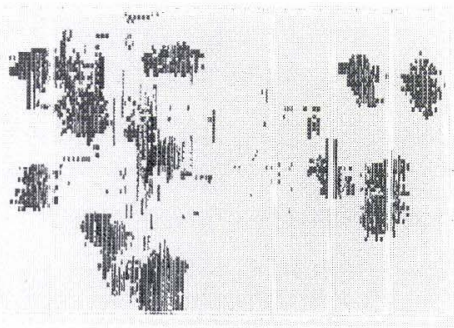

Fig. 10 Implementation of logic circuit to detect planar motion object 


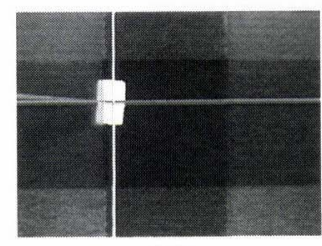

(a)

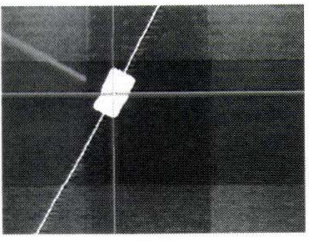

(e)

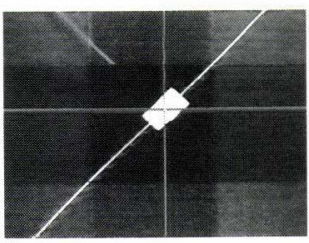

(i)

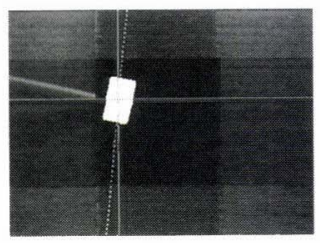

(b)

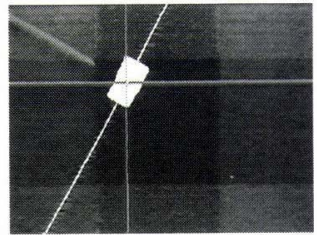

(f)

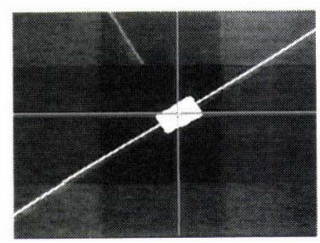

(j)

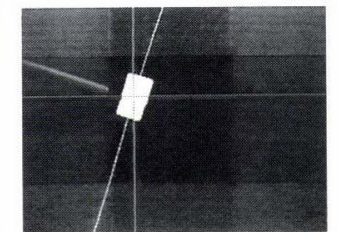

(c)

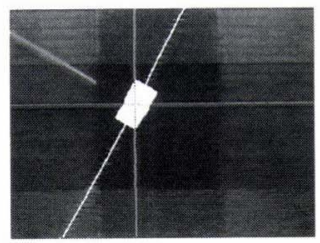

(g)

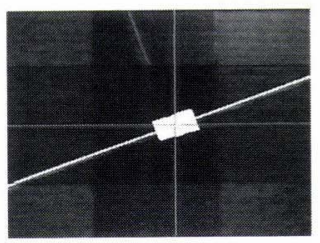

(k)

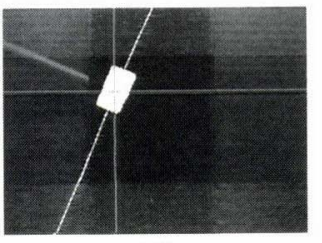

(d)

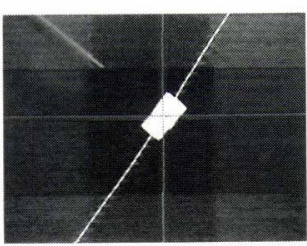

(h)

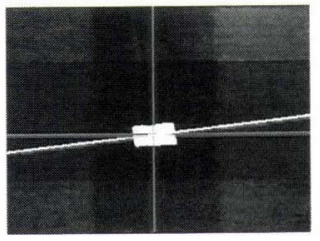

(1)

Fig. 11 Detection of position and orientation

素に対する投票には 1 クロック要するので, 放射状射影の計算に は，1×256×256クロックが必要である。これは，5.46 [msec] に相当する。ただし，画像のキャプチャと並行して実行される ので，放射状射影の計算は画像のキャプチャとともに完了する. 一方, 射影間のマッチングに $64 \times 64$ クロックを要しているた め, 位置と姿勢の検出は, キャプチャ後約 $341[\mu \mathrm{sec}]$ で完了す る. Fig. 11 に, 平面運動物体の位置と姿勢の検出例を示す. 水 平線と垂直線が物体の位置を, 斜めの直線が算出された姿勢を 表す。四に示すように，物体の位置と姿勢をリアルタイムで計 算することができる。

\section{3 ハフ変換}

ハフ変換を計算し，変換結果を出力する論理回路を FPGA 上に実装した。ハフ変換の結果は, FPGA 内の特別な領域であ るブロック RAMに書き込む. 回路設計においては, CycleC による回路記述に対してシミュレーションを実行することによ り, 回路記述を検証する. Fig. 12 に，C言語で記述したソフト ウェアによりハフ変換を実行した結果と, 八フ変換の回路記述 のシミュレーションによりハフ変換を実行した結果を示す. 双 万がほぼ一致しており, CycleCによる回路記述が正しいことを 示す.八フ変換回路による変換結果の出力例を, Fig. 13 に示 す. 画面中央部 $256 \times 256$ [pixel] の領域に対してハフ変換を計 算し, その結果を画面中央下部に表示する. 角度 $\theta$ は, 144 段 階で表される.すなわち, 角度の分解能は $2.5^{\circ}$ である. 距離 $\rho$ は，-127 [pixel] から 127 [pixel] まで 128 段階で計算する。す なわち, 距離の分解能は 1 [pixel] である.このとき FPGA は, 77\%のゲートを使用した. Fig. 14 に, 実装回路で消費された FPGA のゲートを示す. 回路は, $24[\mathrm{MHz}]$ で駆動することが できた。一画素に対する投票には 2 クロック要するので，八フ 変換の計算には, $2 \times 256 \times 256$ クロックが必要である.これ

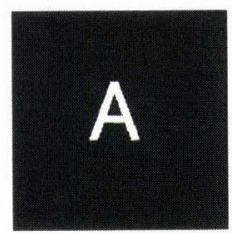

(a) Input

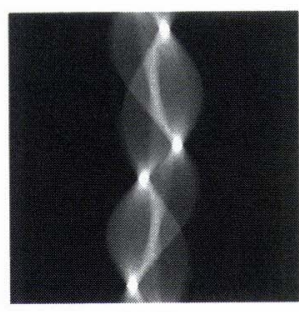

(b) Software

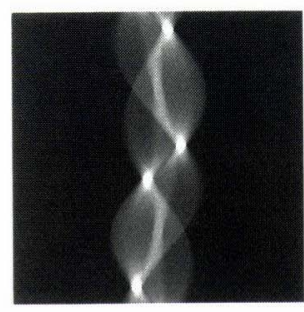

(c) Simulation
Fig. 12 Hough transfroms by software and by simulation of logic circuit

は，5.46[msec] に相当する．ただし，画像のキャプチャと並行 して実行されるので，八フ変換の計算は画像のキャプチャとと もに完了する.Fig. 15 に，八フ変換の計算例を示す. 図に示 すように, 入力画像に対するハフ变換をリアルタイムで計算す ることができる.

なお, 平面運動を検出する回路, 八フ変換を計算する回路と もに，LSI 回路設計を専門としない設計者が，約半年で完成さ せている。

\section{5. おわりに}

本論文では, FPGA ベースリアルタイムビジョンシステムを 紹介するとともに, 画像重心と放射状射影を用いて平面運動物 


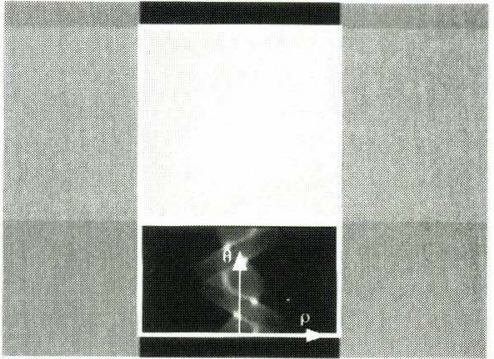

Fig. 13 Image and its Hough transform

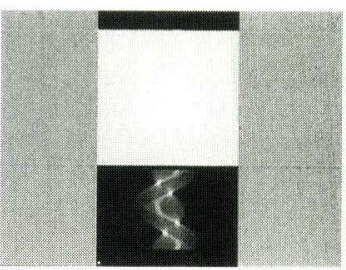

(a)

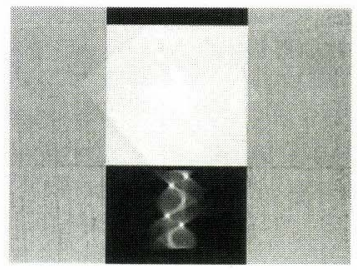

(e)

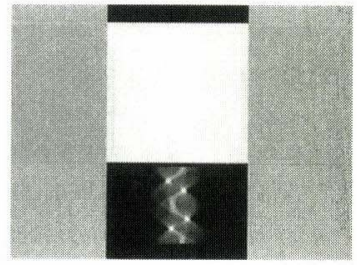

(i)

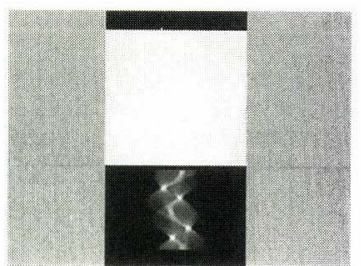

(b)

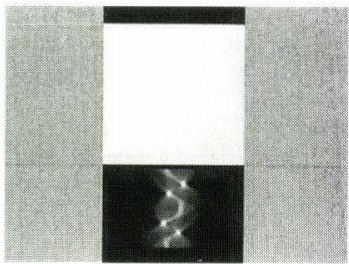

(f)

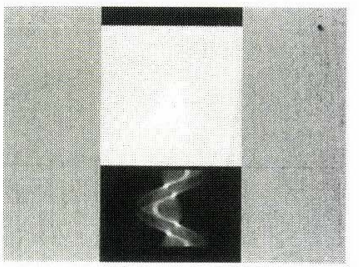

(j)

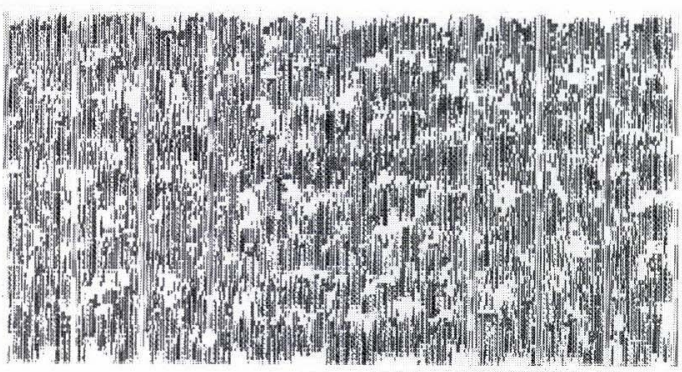

Fig. 14 Implementation of logic circuit to compute Hough transform

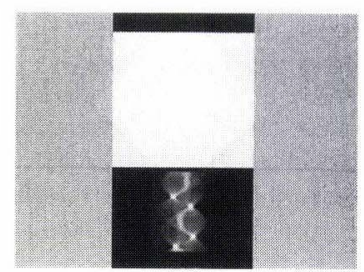

(c)

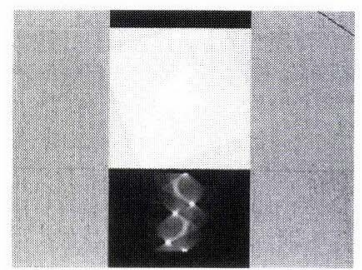

(g)

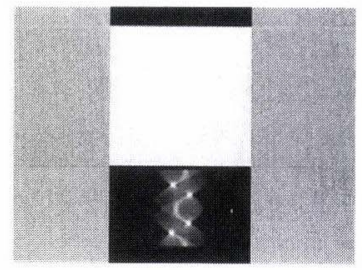

(k)

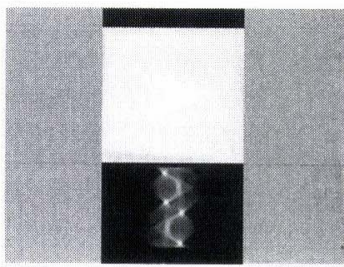

(d)

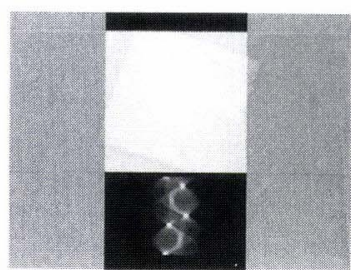

(h)

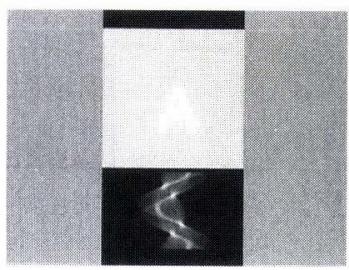

(1)

Fig. 15 Realtime computation of Hough transform

体の位置と姿勢を算出するアルゴリズムを実装した結果を述べ たそその結果， 200 万ゲート相当の FPGA の $15 \%$ 以下のゲー ト数で，アルゴリズムを実装できることが分かった。計算時間 は約 $5[\mathrm{msec}]$ である。ただし，画像のキャプチャと並行して計 算が実行されるため，キャプチャ後約 $0.3[\mathrm{msec}]$ でアルゴリズ ムが完了する。また，八フ変換の計算を実装した結果，200万 ゲート相当の FPGA の $80 \%$ 程度のゲート数を消費することが 判明した。これは，バッファをFPGA 内に構築したためであ り，バッファをSRAM 内に構築することによりゲート数を削減 することが可能である、計算時間は約 $5[\mathrm{msec}]$ である。ただし， 画像のキャプチャとともに，八フ变換の計算が完了する。以上 のように, FPGA ベースリアルタイムビジョンシステムを用い ることにより，計算時間の短縮のみならず，時間遅れの短縮を 実現することができる。また，アルゴリズムの FPGA への実 装では, $\mathrm{C} / \mathrm{C}++$ 言語ベースの回路設計を用いた。結果として, 平面運動検出回路やハフ变換計算回路を, それぞれ約半年で完
成させることができた。設計者は LSI 設計を専門としていない ため, ハードウエア記述言語のみによる設計では, 同じ期間で アルゴリズムを実装することは不可能であったと考える.

現在, バッファを含めてすべての回路を FPGA 内に実装して いる、バッファを外部の SRAMに実装することにより，計算量 がさらに多いアルゴリズムを実装することができる，整合フィ ル夕 [15] や位相限定相関法 [16], 八フフーリエ変換法, 一般化 ハフ変換 $[17]$ は, 平面運動物体の位置と姿勢をロバストに検出 でき，照明変動や対象物体の欠けなどに対応できることが知ら れている。しかしながら,これらのアルゴリズムは, 一次元 $/$ 二次元フーリ工変換, 八フ変換, 極座標変換など, 計算量の多 い演算を必要とし，アルゴリズムをリアルタイムに実行するこ とを困難にしている。これらのアルゴリズムを FPGA ベース ビジョンに実装し，リアルタイムで実行することが今後の課題 である。ビジョンアルゴリズムの計算時間を短縮し, CCD カ メラ以上のフレームレートが実現できる CMOSイメージセン 
サからの画像を用いて位置と姿勢を検出すること, CPU 内蔵 の FPGA を用いて, 認識や判断を含むビジョンアルゴリズム を実装することも今後の課題である.

謝 辞 本研究の一部は, 新エネルギー・産業技術総合開発 機構（NEDO）地域新生コンソーシアムの援助を受けた.

\section{参 考 文 献}

[1] C.D. Thompson: "Fourier Transforms in VLSI," IEEE Trans. on Computers, vol.C-32, no.11, pp.1047-1057, 1983.

[2] M. Maresca, M. Lavin and H. Li: 'Parallel Hough Transform Algorithms on Polymorphic Torus Architecture', Levialdi, S. eds., Multicomputer Vision. Academic Press, pp.9-21, 1988.

[3] H. Inoue, T. Tachikawa and M. Inaba: "Robot Vision System with a Correlation Chip for Real-time Tracking, Optical Flow and Depth Map Generation," Proc. IEEE Int. Conf. on Robotics and Automation, pp.1621-1626, Nice, May, 1992.

[4] A. Bugeja and W. Yang: "A Reconfigurable VLSI Coprocessing System for the Block Matching Algorithm," IEEE Trans on VLSI Systems, vol.5, no.3, pp.329-337, 1995.

[5] M. Hariyama, T. Takeuchi and M. Kameyama: "VLSI Processor for Reliable Stereo Matching Based on Adaptive WindowSize Selection," Proc. 2001 IEEE Int. Conf. on Robotics and Automation, pp.1168-1173, Seoul, May, 2001.

[6] J.-E. Eklund, C. Svensson and A. Aström: "VSLI Implementation of a Focal Plane Image Processor - A Realization of the Near-Sensor Image Processing Concept," IEEE Trans. on VLSI Systems, no.4, vol.3, pp.322-335, 1996.

[7] I. Ishii, Y. Nakabo and M. Ishikawa: "Target Tracking Algorithm for $1 \mathrm{~ms}$ Visual Feedback System using Massively Parallel Processing Vision," Proc. 1996 IEEE Int. Conf. on Robotics and Automation, pp.2309-2314, Mineapolis, May, 2001.
[8] R. Woods, D. Trainor and J.-P. Heron: "Applying an XC6200 to Real-Time Image Processing," IEEE Design \& Test of Computers, vol.15, no.1, pp.30-38, 1998.

[9] 安永, 高見, 吉原: “FPGA を用いたナ/秒オータ画像処理ハード ウエア”, 電子通信情報学会誌, vol.J84-D-II, no.10, pp.2280-2292, 2001.

[10] 永㴊, 吉永, 横田, 大津, 馬場：“並列 FPGA システムによる医療 用画像処理の高速化”, 電子情報通信学会技術研究報告 CPSY2001, vol.101, no.217, pp.1-6, 2001.

[11] S.O. Memik, A.K. Katsaggelos and M. Sarrafzadeh: "Analysis and FPGA Implementation of Image Restortion under Resource Constraints," IEEE Trans. on Computers, vol.52, no.3, pp.390-399, 2003

[12] D.D.S. Deng and H. ElGindy: "High-speed Parameterisable Hough Transform Using Reconfigurable Hardware," Proc. PanSydney area Workshop on Visual Information Processing, pp. 51-57, 2001.

[13] T. Tsuboi, A. Masubuchi, S. Hirai, S. Yamamoto, K. Ohnishi and S. Arimoto: "Video-frame Rate Detection of Position and Orientation of Planar Motion Objects using One-sided Radon Transform," Proc. IEEE Int. Conf. on Robotics and Automation, vol.2, pp.1233-1238, Seoul, May, 2001.

[14] H. Onishi and H. Suzuki: "Detection of Rotation and Parallel Translation Using Hough and Fourier Transforms," Proc. 1996 Int. Conf. on Image Processing, vol.3, pp.827-830, 1996.

[15] G.L. Turin: "An Introduction to Digital Matched Filters," Proceedings of the IEEE, vol.64, no.7, pp.1093-1112, 1977.

[16] Q. Chen, M. Defries and F. Deconinck: "Symmetric PhaseOnly Matched Filtering of Fourier-Mellin Transforms for Image Registration and Recognition," IEEE Trans. PAMI, vol.16, no.12, pp.1156-1168, 1994.

[17] D.H. Ballard: "Generalizing the Hough Transform to Detect Arbitrary Shapes," Pattern Recognition, vol.13, no.2, pp.111122,1981 .

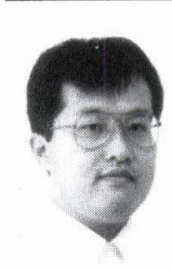

平井慎一 (Shinichi Hirai)

1963 年 3 月 19 日生. 1990 年京都大学大学院工 学研究科博士課程数理工学専攻単位取得退学. 同 年大阪大学工学部電子制御機械工学科助手. 1995 年同助教授. 1996 年立命館大学理工学部ロボティ クス学科助教授, 2002 年同教授となり, 現在に至 る。1989 年米国マサチューセッツ工科大学客員研 究員. 1990 年度計測自動制御学会論文賞. 1996 年度日本機械学会 ロボティクスメカトロニクス部門業績賞. 柔軟物ハンドリング, リア ルタイムビジョン, 分散マニピュレーションなどの研究に従事. 日本 機械学会, 計測自動制御学会, 電子情報通信学会, IEEEなどの会 員.

(日本ロボット学会正会員)

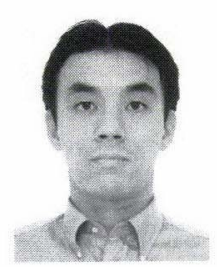

増㴊章洋 (Akihiro Masubuchi)

1976 年 10 月 16 日生. 2000 年立命館大学理工学 部ロボティクス学科卒業. 2002 年立命館大学理工 学研究科修上課程情報システム学専攻修了. 同年, ソニー株式会社に入社し，現在に至る。

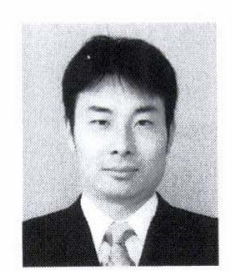

座光寺正和（Masakazu Zakouji）

1978 年 10 月 3 日生. 2001 年立命館大学理工学部 ロボティクス学科卒業. 2003 年立命館大学理工学 研究科修士課程情報システム学専攻修了. 同年, 七 イコーエプソン株式会社に人社し，現在に至る.

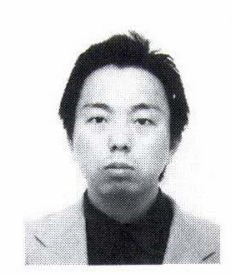

坪井辰彦（Tatsuhiko Tsuboi）

1976 年 1 月 7 日生. 1998 年立命館大学理工学部機 械工学科卒業. 2000 年同大学大学院修士課程修了. 現在, 同大学大学院博士後期課程在学中. ロボット ビジョンに関する研究に従事。電子情報通信学会, IEEE 各学生員.

(日本ロボット学会正会員) 